\title{
An Examination of the Causes of Students-Management Conflicts in University for Development Studies from 1999 to 2009
}

\author{
John Yaw Akparep \\ Department of Management Studies, School of Business and Law, University for Development Studies, Wa Campus, Wa, Ghana \\ Email: jakparep@uds.edu.gh
}

How to cite this paper: Akparep, J. Y. (2019). An Examination of the Causes of Students-Management Conflicts in University for Development Studies from 1999 to 2009. Open Journal of Leadership, 8, 75-94. https://doi.org/10.4236/ojl.2019.82005

Received: April 18, 2019

Accepted: June 18, 2019

Published: June 21, 2019

Copyright ( 2019 by author(s) and Scientific Research Publishing Inc. This work is licensed under the Creative Commons Attribution International License (CC BY 4.0).

http://creativecommons.org/licenses/by/4.0/

Open Access

\begin{abstract}
Effective conflict resolution demands that causes of conflicts should be known. University for Development Studies (UDS) over the years had been plagued by many students-management conflicts like other universities in Ghana. This paper therefore examines the causes of those students-management conflicts in UDS from 1999 to 2009. Questionnaires and interview guides were the data collection tools employed and administered to 40 respondents who were purposely selected in a case study design. Data were analyzed qualitatively in narratives and with tables and graphs. The study identified a number of causes of the conflicts which notably included: wide communication gap between students and school management, delay in meeting students' demand by school management, failure by school management to guarantee security of lives and properties, inadequate facilities such as lecture rooms, laboratories and equipment and drastic and obnoxious rules and regulations. Other causes were: students being forced to pay special fees/hikes in students' fees, the activities of campus secret cults and differences in the perception of group and organizational objectives. This paper concluded that wide communication gaps between students and university management, infrastructural deficiencies and leadership crises were the major drivers of the conflicts in UDS from 1999 to 2009 . The paper recommended that efforts be made to enhance communication at all levels of the University especially between students and management, involve students in decision making, improve students-management dialogues, provide adequate infrastructure and provide effective institutional leadership.
\end{abstract}

\section{Keywords}

Conflicts, Cause, Organizational Conflicts, Management, Tertiary Institutions, UDS 


\section{Introduction}

Conflicts abound in decisions administrators make about students (Bua et al,, 2015). This is as a result of the many different stakeholder interactions that take place in the university environment. Wall \& Callister (1995: p. 517) defined conflict as "a process in which one party perceives that its interests are being opposed or negatively affected by another party". In examining the problems of university management in Nigeria, Ekundayo \& Ajayi (2009) citing Ibukun (1997) indicated that university governance in Africa as in Nigeria is nothing but crises management. The situation in Ghana is not different. Records show that from 1999 to 2009, the University for Development Studies (UDS), the study focus, experienced various levels of students-management conflicts on the various campuses. The University experienced students-management conflicts in the 1999/2000 academic year on Nyankpala Campus, 1999/2000, 2001/2002 and 2004/2005 academic years on Navrongo and 2005/2006 academic year and 2008/2009 academic year on Wa Campus. These conflicts were of serious concern to the University (UDS, 2009; 2011; Boateng, 2008). Apparently, much as these conflicts were said to have impacted the university seriously, no scholar work has been done intently as to unravel the various factors that might have given rise to these conflicts.

Understanding the factors that give rise to conflicts is one major productive way of resolving organizational conflicts (Stone, 1999). Ada (2013) proposed two models to the analysis of conflict in educational institutions-structural and process models. These models find their relevance in aiding the understanding and effective management of school based conflicts. According to the structural model, the best way to understand a particular conflict is to focus on circumstances that initiate, condition and direct such conflict behavior in a relationship such as formal organizational roles and informal group membership (Ada, 2013). The process model on the other hand, examines the series of occurrences of the conflicts so as to understand and step into the process. To manage conflict from the structural point of view, there is the need to reshape circumstances that led to the conflict. As noted by Rothman (1992), when symptoms instead of causes are addressed, wounds are merely bandaged, not healed and they may fester.

It is against this background that this paper seeks to ascertain what caused the students-management conflicts in the University for Development Studies from 1999 to 2009. It is envisaged that the findings from this paper will help stakeholders to formulate pragmatic policy targeting students-management conflicts in UDS in particular and tertiary institutions in general in Ghana.

\section{Literature Review}

\section{An Overview of Causes of Students-Management Conflicts in University Organizations}

Extant literature has identified a number of factors contributing to students-management conflicts. According to Adeyemi et al., (2010), causes of stu- 
dents-management conflicts in tertiary institutions vary. Adeyemi et al. (2010) study revealed that communication gap between students and the school authorities was the major cause of students-management conflicts accounting for about $82 \%$ including what they referred to as structural factors and personal behavior factors. Buttressing the point, Havenga \& Visagie (2011) identified communication factors as the basic forces or causes of conflict. Indeed, when there is communication breakdown as in the words of Kreitner (2001) between students and management, conflicts would arise. Ajibade (2013) and Olaleye \& Arogundade (2013) agreed to this point when they stated that poor communication between institutional authorities and students is a major drive to students-management conflicts.

The literature has identified needs denial as another cause of conflicts in educational institutions. In Abraham Maslow's (1943) needs hierarchy, security needs are given prominence; coming next only to physiological needs (Hellriegel \& Slocum, 2011). In their analysis of Maslow's needs hierarchy, Hellriegel \& Slocum (2011) observed that security needs are the desire for safety, stability and the absence of pain, threator illness and that, like physiological needs, unsatisfied security needs cause individuals to be preoccupied with satisfying them. Preoccupation in satisfying security needs could be constructive as in negotiation or destructive as in battling. The latter, though not preferable is resorted to when options are exhausted-hence conflicts. So as in the study of Adeyemi et al. (2010), up to $88.8 \%$ of their respondents noted that failure on the part of school authorities to guarantee security of lives and properties was a cause of students-management conflicts in tertiary institutions. This finding was in line with Adebayo's (2009) work. Adebayo's (2009) study revealed that one of the most sensitive causes of students-management conflicts was when the management failed to guarantee security of lives and property on campus. Adepoju \& Sofowora (2012) conclude that this amounts to insensitivity of management to students' welfare which leads to students-induced conflict and aggressive behavior.

Ajibade (2013) has identified the lack of university amenities as another source of students-management conflicts; indicating that many tertiary educational institutions lack basic amenities like functional laboratory, well equipped library, sports equipment and adequate hostel with functional facilities like water and light among others, necessary for successful academic enterprises. Thus, poor infrastructure as well as the inadequacy of it could cause students to rise up against university management. It should be noted that, whereas the desire for university education is on the increase causing increases in university enrollment, there is relatively no corresponding increase in university infrastructure. Lecture halls, students' hostels, water supply systems, library space with books and journals laboratories remain a challenge to universities. As observed by Ige (2014), most institutions cannot accommodate many students at a time, thus, making many students to often run to secure seats to receive lectures. $\mathrm{He}$ observed that many students are fond of receiving lectures on their feet, outside classrooms, rather than on their seats. 
Adebayo (2009) intimates that when educational facilities are inadequate, it could be enough to upset the peace between the students and the universities authorities.

Student political leaders' activities, external political influence, as well as organizational politics to some extent contribute to students-management conflicts. Whilst campaigning for leadership positions, student politicians often look at issues of serious concern to students, promising to deal with them when elected into office. Attempts to fulfill these promises which may be incompatible to management's decisions and so are unmet or delayed management's attempts to meet such demands lead to clashes between the two. The situation becomes worse when leadership of management does not have the necessary skills to deal with conflicts. This is particularly the case when some Vice Chancellors are appointed due to political considerations without much regards to competence in university management. One other important dimension to this argument is where university staff incites students against management to address issues that bother on student's welfare and by extension that of the staff. For a number of situations when students agitate for the removal of a vice chancellor from office, employees are often behind the move. The situation fits into what Ekundayo \& Ajayi (2009) refer to as militant student unionism. This way, student unions reacting aggressively to problems in the university often lead to student management conflicts.

Denial of students' freedom has been cited as one principal source of conflicts within the university fraternity. For example, students from the University College of Ibadan, Nigeria were cited to have staged the first ever protest in 1957 over barbed-wire barricade that was allegedly set up to control the unlawful movement of students out of halls of residence (Adebayo, 2009). There was leadership lapse (Akparep, Jengre, \& Mogre, 2019). It is important that in formulating rules and regulation that are binding on students, care be taken to avoid extremes or they result in students protests. Alabi (2002: p. 3) observed that the older members of the university_ "academic and administrators often impose rules and regulations". In return, "the young may answer back by demanding for, and claiming, their democratic rights, culminating in minor conflicts or even ghastly skirmishes between the students and the university authority".

At the school situation, joint decision-making between management and student in matters that affect the interest of students is critical in promoting an atmosphere of peace. Adepoju \& Sofowora (2012) in a study found agitation for students' involvement in management as a source of student management conflicts. Unfortunately, as happens in most instances, university management retains most of the authority. Management makes decisions confidently and assumes that students will comply, and are not overly concerned with students' attitudes toward the decisions (DuBrin, 2010). These decisions often appear not only as foreign imposition on the students but also, alien creations which often evoke students protest; resulting in student management conflicts. Students' non-involvement in decisions that concern their welfare thus had $82.0 \%$ of Adeye- 
mi et al.' (2010) respondents agreeing as being a cause of students-management conflicts.

Adeyemi, et al., (2010) on their part have noted that when students are been compelled to pay a special fee, especially when management cannot adequately justify reasons for the payment, such act generates conflict between students and management. Adebayo (2009) cited an example where in 1971 a second year undergraduate of the University of Ibadan lost his life in the protest that originated from issues that included increase in tuition fees. Adebayo therefore concluded that, when school fees and registration fees are too high for students to pay, they might protest resulting in conflict between them and management.

The activities of secrete cults popularly called occultism, referred to as witchcraft, satanism, neo-paganism, or any of the various forms of psychic discernment such as astrology and palm reading among others (Lawson, 2009) are said to be on the increase on university campuses and also posing as threat to lives and campus security generally. Though the situation may not be widely pronounced in Ghana as the case of Nigeria, it remains an issue of concern on campuses of Ghanaian Universities (UDS, 2010; Ekundayo \& Ajayi, 2009). The membership aggressiveness also poses a challenge to the management of tertiary institutions (Ekundayo \& Ajayi, 2009). Adegbite (2007) and Smah (2007) in Ajayi \& Ekundayo (2008) and Ogunbameru (2004) observed that the activities of the secret cults are fast escalating and pose danger to the development of educational institutions. For these researchers, the existence of the secret cults does not guarantee the smooth running of academic programmes and activities and that their existence lead to frequent disturbances and disruption of university activities as well as the creation of the feeling of fear and campus insecurity and campus killings and deaths (both physical and ritual). Students in these cults often develop the culture of not only terrorizing their colleague students but also resisting authority in most cases through militant student unions which result in students-management conflicts. Unfortunately it is noted that cultists usually prove difficult to be arrested by administrators of the institutions and that even when captured are often handled as "sacred cows" (Ige, 2014).

The discussions above suggest that the factors that contribute to confrontation between management and students on university campuses are many and varied. Attempts to promote peace on university campuses therefore demand in-depth knowledge about these contributory factors. As noted by Stone (1999), conflicts do not arise without a cause, and they do not disappear until the cause is addressed.

\section{Methodology}

\subsection{Study Locality}

The University for Development Studies (UDS) was purposely chosen because of its uniqueness and the fact that it had also witnessed a number of students-management conflicts between 1999 and 2009. UDS is unique in the sense that it is the only University in Ghana that operates a trimester system with the 
third trimester devoted to community work. Also, it was the first public university in Ghana established to be autonomous without affiliation to another University. Another unique feature of the University lies in its multi-campus based nature by law at inception, a deviation from the usual practice of having universities with centralized campuses and administrations. UDS, Tamale, was established in 1992 as a multi-campus institution. It is the fifth public university to be established in Ghana. The University currently has campuses in the three Northern Regions of the country: the Northern Region, Upper East Region and the Upper West Region (UDS, 2016). The uniqueness of the University lends itself to a number of crises including students-management conflicts. As Ada (2013) observed, "tertiary institutions are always in crises when conflicts occur, which vary from campus to campus depending on the size, location, student population, mission, specialization, governance and unionization. What can trigger conflict, perhaps even large scale ones, on one campus may be inconceivable on another". This paper on the University for Development Studies is therefore on its own merit and not in comparison with other Universities.

\subsection{Research Design}

This paper adopted the qualitative research design. Creswell (2014) defined qualitative research design as "an approach for exploring and understanding the meaning individuals or groups ascribe to a social or human problem" and that by qualitative design, data are typically collected in the participant's setting, data analysis inductively building from particular to general themes, and the researcher making interpretations of the meaning of the data. The designed enabled the researcher to understand the causes of students-management conflicts from the perspective of both students and management.

\subsection{Selection of Research Participants}

According to Babbie (2005), sampling units also referred to as elements are about those people or certain types of people from whom information is collected for analysis in research. Burgess (2001) explained that a sample is a sub-set of the population that is usually chosen because to access all members of the population is prohibitive in time, money and other resources. For this study, a pre-research investigation estimated that each of the campuses of the University that witnessed students-management conflicts during the study period had Students Representative Council (SRC) Executive Committee of four members and Local Branch of National Union of Ghana Students (NUGS) of four members who represented all students. Thus, for the campuses in the six conflict situations, these leaders summed up to 48 . Twelve of these 48 student leaders, representing $25 \%$ (two from each campus) who were in office as student leaders during the six noted students-management conflicts who were available and willing were considered for the study to generate a wider students' perspective on the issue. Besides, a total of 28 non student respondents were purposely selected bringing the total sample size to 40 . Table 1 depicts the 28 non-student respondents. 
Table 1. Summary of selected Non Student Respondents.

\begin{tabular}{|c|c|c|}
\hline Type of respondent & Description of respondent & Number of respondents \\
\hline Senior Hall Tutors & $\begin{array}{l}\text { One from each campus where the conflicts } \\
\text { occurred }\end{array}$ & 4 \\
\hline Deans of Students & As were in the University during the conflicts & 2 \\
\hline Vice Deans of Students & $\begin{array}{l}\text { As were on the campuses of the conflicts } \\
\text { during the period considered for the study }\end{array}$ & 1 \\
\hline $\begin{array}{l}\text { Deans-In-Charge of } \\
\text { Campuses }\end{array}$ & $\begin{array}{l}\text { As were on the campuses of the conflicts } \\
\text { during the period considered for the study }\end{array}$ & 6 \\
\hline $\begin{array}{l}\text { Faculty Officers of the } \\
\text { Faculties-In-Charge }\end{array}$ & $\begin{array}{l}\text { As were on the campuses of the conflicts } \\
\text { during the period considered for the study }\end{array}$ & 4 \\
\hline Registrars & $\begin{array}{l}\text { As living Registrars who were in the } \\
\text { University during the conflicts }\end{array}$ & 2 \\
\hline Pro Vice Chancellors & As were in the University during the conflicts & 3 \\
\hline $\begin{array}{l}\text { Director of Works and } \\
\text { Physical Development }\end{array}$ & As was in the University during the conflicts & 1 \\
\hline University Librarian & As was in the University during the conflicts & 1 \\
\hline Campus Head of Security & $\begin{array}{l}\text { As were on the campuses of the conflicts } \\
\text { during the period considered for the study }\end{array}$ & 3 \\
\hline $\begin{array}{l}\text { A Retired Senior Police } \\
\text { Officer }\end{array}$ & $\begin{array}{l}\text { Knowledgeable in students oriented } \\
\text { conflicts }\end{array}$ & 1 \\
\hline Grand total & & 28 \\
\hline
\end{tabular}

Source: Author's construct, 2017.

The study adopted non-probability sampling techniques. Twumasi (2001: p. 26) was emphatic that in using non-probability sampling techniques for a study, the selection of a sample does not call for systematic sampling procedures. For Twumasi, "the researcher decides to take what he/she thinks is the representative unit of the group" being studied based on his/her knowledge of the study objectives and the extent of error he/she kis able to deal with. Sarantakos (2005: pp. 170-171) said that the wise qualitative rule in deciding the sample size is to make sure it is as large as necessary and as small as possible noting that large samples do not always guarantee a higher degree of precision and validity. For this study, the purposive sampling (judgmental sampling) and the snowball sampling techniques of the non-probability sampling technique were relied on.

The purposive sampling was used based on the researcher's knowledge of the units and their ability to answer the research questions. The snowball sampling technique was also used in this study to enable the researcher reach respondents who were not easy to locate for data. In this situation, the researcher collected data from the few known and located elements of the study population who in turn suggested and provided information about other members of the population they knew; helping him to locate them for data. The purposive sampling 
technique was used with the snowball technique in the selection of the Deans of Students, Vice Dean of Students, Deans-In-Charge of Campuses, Faculty Officers of the Faculties-In-Charge, Registrars, Pro Vice Chancellors, Director of Works and Physical Development, the University Librarian and the heads of campus security personnel (Officers during whose time in office the conflicts occurred) as well as the Retired Senior Police Officer who was knowledgeable in students' oriented conflicts for the study. Snowball sampling technique was also used to select the four Senior Hall Tutors who were in office during the conflicts on the campuses; making up the 28 non student respondents of the study.

\subsection{Data Collection Methods and Tools}

For the data collection, the in-depth interview technique was used. Mason (2002) postulated that interview is the most dominantly known and used qualitative data collection method. "An interview is a method of field investigation whereby the researcher meets respondents and through the interaction asks specific questions to find answers to his/her research problem" (Twumasi, 2001: p. 35). Although interviews assume the form of questionnaires, they are administered verbally and are very useful in generating specific and in-depth qualitative data on the problem of study (Baker, 1994; Twumasi, 2001; Sarantakos, 2005). Marshal and Rossman (1995) asserted that qualitative researchers have often depended largely on in-depth interviews in their research endeavours and that even in some instances it is the only technique the researchers depend on. The adoption and use of interviews was also motivated by Gray's (2004: p. 214) assertion that interviews help in among other things in attaining more personalized data and ensuring good return rate. This study was modeled along the general interview guide approach. Interview guide takes the form of guide rather than rules and interviewees are expected to answer freely (Denzin, 1989; Flick, 2002; Sarantakos, 2005). The guide gives the researcher the opportunity to evaluate and adjust given research points to make results more valid and reliable. In doing interviews, it might also be necessary to sample respondents when the population is large and cannot all be interviewed. For this study, in-depth interviews were conducted from November, 2016 to January, 2017 on 12 past student leaders and 28 management members of the University. Meetings were arranged with these respondents by the researcher and questions administered to them. Thus, a total of 40 in-depth interviewees were used for the study.

The in-depth interview technique was augmented with surveys questionnaire administration which Marshall \& Rossman (1995: p. 86) referred to as "supplemental data collection techniques" for qualitative studies. To arrive at valid and reliable research results, the study also resorted to the consultation of more than one source of data such as primary and secondary sources which Denzin in Flick (2002: p. 226) referred to as data triangulation. Secondary sources of data for this study included articles, published and unpublished books, internet, and newspaper publications on students-management conflicts and their related issues. The analysis of data was mainly narrative. Graphic formats like graphs, tables 
and matrices produced from excel to aid appropriate presentation, description and interpretation were also used. Miles \& Huberman (1984) and Marshal \& Rossman (1995) believe that using the graphic formats help researchers to summarize results of analysis.

\section{Findings and Discussion}

\section{Causes of Students-Management Conflicts in UDS from 1999 to 2009}

The causes of conflicts between students and management of the University during the period studied captured under Table 2 and Table 3 respectively reflecting the views of both students and management. The causes were identified by respondents and classified according to the rate at which they were perceived to be responsible for the conflicts. The rating was done on a likert scale of: very high,

Table 2. Students' rating of the causes of students-management conflicts in UDS from 1999 to 2009.

\begin{tabular}{|c|c|c|c|c|c|c|c|}
\hline $\mathrm{S} / \mathrm{N}$ & Factors responsible & Very high & High & Moderate & Low & \multicolumn{2}{|c|}{ Very low Total } \\
\hline & & & & $\%$ & & & \\
\hline 1 & Wide communication gap between students and school management. & 25 & 66.7 & 8.3 & 0 & 0 & 100 \\
\hline 2 & Delay in meeting students' demand by school management. & 16.7 & 58.3 & 25 & 0 & 0 & 100 \\
\hline 3 & $\begin{array}{l}\text { Failure by school management to guarantee security of lives and } \\
\text { properties }\end{array}$ & 0 & 16.7 & 25 & 41.6 & 16.7 & 100 \\
\hline 4 & $\begin{array}{l}\text { Inadequate facilities such as lecture rooms, laboratories and } \\
\text { equipment }\end{array}$ & 25 & 58.3 & 16.7 & 0 & 0 & 100 \\
\hline 5 & Drastic and obnoxious rules and regulations. & 0 & 16.7 & 16.7 & 50 & 16.7 & 100 \\
\hline 6 & Frustration and uncertainty from the larger society & 0 & 0 & 16.7 & 66.7 & 16.7 & 100 \\
\hline 7 & Students' non-involvement in decision that concern their welfare & 8.3 & 25 & 58.3 & 8.3 & 0 & 100 \\
\hline 8 & Students being forced to pay special fees/hikes in students' fees & 16.7 & 33.3 & 25 & 16.7 & 8.3 & 100 \\
\hline 9 & The activities of campus secret cults & 0 & 0 & 0 & 25 & 75 & 100 \\
\hline 10 & Differences in the perception of group and organizational objectives & 0 & 16.7 & 16.7 & 58.3 & 8.3 & 100 \\
\hline 11 & Poor institutional leadership & 8.3 & 41.7 & 25 & 16.7 & 8.3 & 100 \\
\hline 12 & $\begin{array}{l}\text { Increasing awareness of students' rights and their power to influence } \\
\text { management decisions }\end{array}$ & 8.3 & 50 & 41.7 & 0 & 0 & 100 \\
\hline 13 & $\begin{array}{l}\text { Influence of complex students' social background and youthful } \\
\text { exuberance }\end{array}$ & 16.7 & 50 & 33.3 & 0 & 0 & 100 \\
\hline 14 & Management role overload & 0 & 0 & 58.3 & 25 & 16.7 & 100 \\
\hline 15 & Widespread corruption allegations on campus & 0 & 25 & 50 & 16.7 & 8.3 & 100 \\
\hline
\end{tabular}

Source: Field Survey, January, 2017. 
Table 3. Management rating of the causes of students-management conflicts in UDS from 1999 to 2009.

\begin{tabular}{|c|c|c|c|c|c|c|c|}
\hline $\mathrm{S} / \mathrm{N}$ & Factors responsible & Very high & High & Moderate & Low & \multicolumn{2}{|c|}{ Very low Total } \\
\hline 1 & $\begin{array}{l}\text { Wide communication gap between students and } \\
\text { school management. }\end{array}$ & 17.9 & 57.1 & 17.9 & 7.1 & 0 & 100 \\
\hline 2 & $\begin{array}{l}\text { Delay in meeting students' demand by school } \\
\text { management. }\end{array}$ & 0.7 & 39.3 & 35.7 & 17.9 & 0 & 100 \\
\hline 3 & $\begin{array}{l}\text { Failure by school management to guarantee security } \\
\text { of lives and properties }\end{array}$ & 0 & 7.1 & 14.3 & 35.7 & 42.9 & 100 \\
\hline 4 & $\begin{array}{l}\text { Inadequate facilities such as lecture rooms, } \\
\text { laboratories and equipment }\end{array}$ & 0 & 53.6 & 46.3 & 0 & 0 & 100 \\
\hline 5 & Drastic and obnoxious rules and regulations. & 0 & 0 & 14.3 & 42.9 & 42.9 & 100 \\
\hline 6 & Frustration and uncertainty from the larger society & 0 & 0 & 7.1 & 50 & 42.9 & 100 \\
\hline 7 & $\begin{array}{l}\text { Students' non-involvement in decision that concern } \\
\text { their welfare }\end{array}$ & 0 & 21.4 & 39.3 & 21.4 & 17.9 & 100 \\
\hline 8 & $\begin{array}{l}\text { Students being forced to pay special fees/hikes in } \\
\text { students' fees }\end{array}$ & 0 & 21.4 & 32.1 & 28.6 & 17.9 & 100 \\
\hline 9 & The activities of campus secret cults & 0 & 0 & 14.3 & 21.4 & 64.3 & 100 \\
\hline 10 & $\begin{array}{l}\text { Differences in the perception of group and } \\
\text { organizational objectives }\end{array}$ & 0 & 7.1 & 35.7 & 42.9 & 14.3 & 100 \\
\hline 11 & Poor institutional leadership & 14.3 & 21.4 & 35.7 & 21.4 & 7.1 & 100 \\
\hline 12 & $\begin{array}{l}\text { Increasing awareness of students' rights and their } \\
\text { power to influence management decisions }\end{array}$ & 14.3 & 21.4 & 35.7 & 25 & 3.6 & 100 \\
\hline 13 & $\begin{array}{l}\text { Influence of complex students' social } \\
\text { background and youthful exuberance }\end{array}$ & 17.9 & 35.7 & 32.1 & 14.3 & 0 & 100 \\
\hline 14 & Management role overload & 0 & 0 & 35.7 & 53.6 & 10.7 & 100 \\
\hline 15 & Widespread corruption allegations on campus & 0 & 7.1 & 21.4 & 42.9 & 28.6 & 100 \\
\hline
\end{tabular}

Source: Field Survey, January, 2017.

high, moderate, low and very low. The results were as displayed on the Table 2 and Table 3.

The views of both students and management about the causes of the conflicts as found in this paper were similar to those identified by Adeyemi et al. (2010), Visagie (2011), Hellriegel \& Slocum (2011) and Ajibade (2013) as the causes of students' crisis in tertiary institutions most especially in Nigeria.

\section{Nature of communication between students and school management}

This study established that there was a wide communication gap between students and school management during the period used for the study. Table 2 and Table 3 above both affirm this. Communication gap was ranked highest as the 
cause of students-management conflicts in the University by both student and management respondents. Up to $66.7 \%$ of the student respondents believed the communication gap between students and school management at the time was high with even an additional $25 \%$ of them rating it as being very high. Only $8.3 \%$ rated the situation as being moderate with none of them indicating it was low or very low. In a similar vein, $57.1 \%$ of management respondents were of the view that there was a high communication gap between students and school management. Further $17.9 \%$ of the management respondents admitted that communication gap between students and school management at the time was very high. However, $17.9 \%$ and $7.1 \%$ of the management respondents were of the view that communication gap between students and school management was only moderate and low respectively; with none indicating it was very low.

The findings in this regard were similar to the work of Adeyemi et al. (2010) where up to $82.9 \%$ of their respondents to a study "Managing Students' Crisis in Tertiary Institutions in Nigeria", identified wide communication gap between students and the school authority as the cause of students' crisis in tertiary institutions in Ondo State, Nigeria. In an interview, a respondent indicated:

"The communication gap between the students and school management was so wide that there were times when students and management were not even ready to engage in any form of discourse. The other causes of conflict could even be discussed and consensus built to avoid conflicts if communication between the two groups in the University were effective" (Interviews, January, 2017).

Probing further, the study found that communication in the University between students and management was largely top-down with information flowing from management to students in the form of decisions taken by management. Accordingly, Kreitner (2001) noted that communication is a complex process beset by many barriers which often provoke conflict and that it is easy to misunderstand another person or group of people if two-way communication is hampered in some way. Majority of the respondents $(82.5 \%)$, both students and management had this view. The remaining $17.5 \%$ of the respondents however, believed that there was a two-way communication in the University between students and management of the University. There was no indication of bottom-up communication in the University. Majority of the respondents of both categories described the state of communication between students and management of the University at the time of the conflicts as ineffective. See Figure 1.

From Figure 1, 70\% of the respondents indicated that the state of communication between students and management of the University at the time of the conflicts was ineffective. Respondents believed that the existing state of communication in the University between students and management influenced the conflicts in a number of ways. This is what a key informant said:

"The existing state of communication prevented students from being heard and their grievances addressed, increased grapevines information, bred misconceptions and led to misunderstandings that largely resulted in the conflicts" (Interviews, January, 2017). 


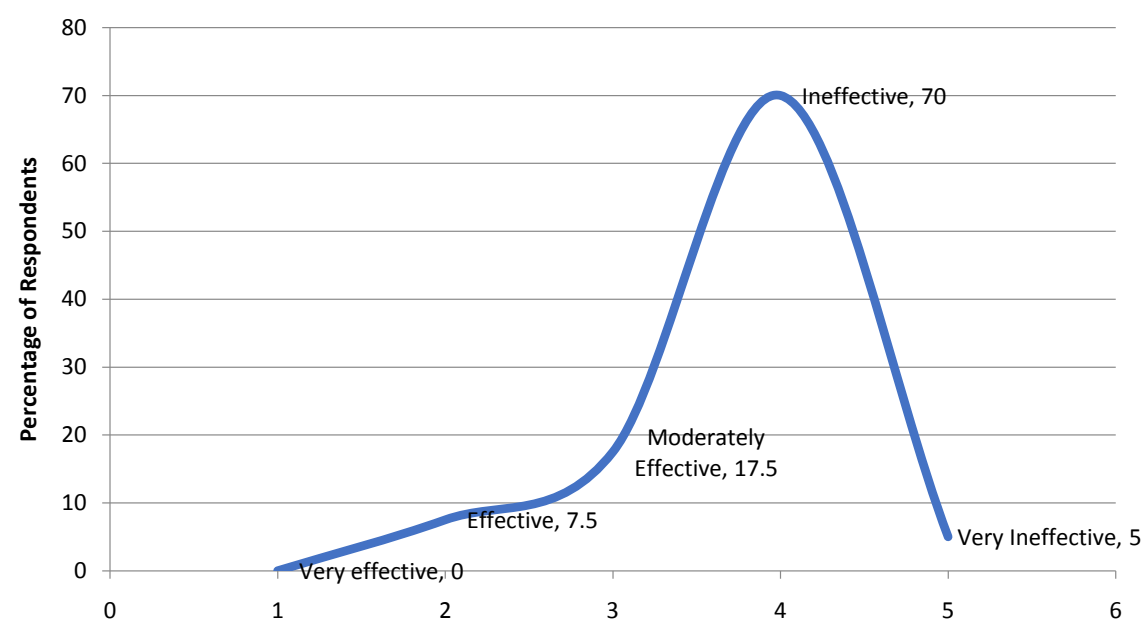

Figure 1. The State of Communication between Students and Management of the University at the Time of the Conflicts. Source: Field Study, January, 2017

The findings from this study were in consonance with Ajibade (2013) and Olaleye \& Arogundade's (2013) argument that poor communication between authorities of institutions and students was a major cause of students-management conflicts. This as the study revealed, was the case in the 2008/2009 conflicts on the Wa Campus of the University.

The State of Infrastructure in the University for Students Academic Activities

The state of infrastructure in the University for Students' Academic Activities, compared to student numbers from 1999 to 2009 as established by the study was not so good. On the scale of highly adequate, adequate, moderately adequate, inadequate and highly inadequate, it was discovered that $80 \%$ of the respondents of both categories selected the inadequacy of infrastructure in the University for Students' Academic Activities. Whereas only 5\% of the respondents felt that infrastructure in the University for Students' Academic Activities was moderately adequate, an additional $15 \%$ asserted that infrastructure in the University for Students' Academic Activities was highly inadequate. None of the respondents either believed infrastructure in the University for Students' Academic Activities was highly adequate or even adequate. A student respondent had this to say:

"On countless occasions, lecturers came to class and angrily left because the lecture halls were overcrowded with students and very noisy with no microphones to deliver lectures to the hearing of all students. Access to water was often a big problem to grapple with. In Navrongo, lecturers had to hunt for water with gallons and students had to queue with natives to fetch water from a stand pump in an arrangement that allowed one student to fetch only after three natives had fetched. There were no toilet and urinal facilities for students use. Sanitation was so poor. We used the campus with animals. They defecated and urinated to make the campus dirty and stinky. Cleaners were lazy and left the campus mostly untidy. Students paid for the use of computers but had no computer laboratories. They paid for health insurance but got not insured and had to 
pay cash to access health care. They were levied for a clinic that was not existing. Students had no adequate furniture for use in the lecture halls. We paid for, yet lacked sporting facilities" (Interviews, January, 2017).

Another respondent from management added:

"The state of infrastructure was bad. In Navrongo, our library looked like a hen coup. In Wa, student numbers were so overwhelming that some of them had to write examinations with broken slaps. There were no hostels until 2007. And even when there were hostels, they were not adequate and so students lived among natives and had so many problems, especially, the female students who had to quarrel with wives of landlords over alleged attempts to snatch their husbands. All these caused stress to students and no doubt contributed to conflicts between students and management" (Interviews, January, 2017).

The findings of this study as discussed above corroborated Ajibade's (2013) identification of the lack of university amenities as a source of students-management conflicts. Ajibade's (2013) indicated that many tertiary educational institutions lacked basic amenities like functional laboratory, well equipped library, sports equipment and adequate hostel with functional facilities like water and light among others, necessary for successful academic enterprises. Findings of the study were also in harmony with Adebayo's (2009) that when educational facilities are inadequate, it could be enough to upset the peace between the students and the universities authorities.

The deplorable nature of the infrastructural situation was often not given swift response and attention by management whenever concerns were raised as was discovered by this study. Although $53.6 \%$ of management respondents believed that management tried to respond to students demands largely on infrastructure as swiftly as possible, the remaining $46.4 \%$ together with $66.7 \%$ of the student respondents had a contrary view. For these percentages of respondents, management lagged in their attempts to respond to students concerns which centered largely on infrastructural requirements for students' academic activities in the University. Further $33.3 \%$ of the student respondents believed that management response to students' demands was even done very laginly. A student interviewee said

"I do not even want to say management showed concern to our complaints regarding infrastructure. Management had no concern for our infrastructural needs. This was a matter of fact. Management was never swift in responding to students' concerns until the situations culminated into open demonstrations by students. The only language management understood was demonstration. Even though students did not always see demonstrations as the best options to dealing with their grievance, they were sometimes compelled to get sympathy through expressing their concerns in demonstrations" (Interviews, January, 2017 nterviews, January, 2017).

The study made efforts to find out the state of stability of the academic environment of the University for academic activities at the time of the conflicts and whether it had anything to do with the conflicts. On this, whereas $41.7 \%$ of the 
student respondents were of the opinion that the academic environment of the University was moderately stable and less frustrating, majority of them (58.3\%) believed that academic environment of the University was unstable and frustrating. There was however, a split management respondents' opinion regarding the situation. That is, whereas, $50 \%$ of them thought that academic environment of the University was stable and less frustrating, the other $50 \%$ believed it was unstable and frustrating.

Students' Representation and Participation in Decision Making Processes

This study tried to find out the various levels of management at which students were represented and participated in decision-making. It was found that students were represented and involved in decision making of the University at such levels as in the University Governing Council, Campus Management and at the Hall Management level. Probing further it was revealed that students were involved in the process of fee fixing/increases in the University. This was contrary to the assertion of Mennon (2003) and Bergan (2003) that students generally lacked participation in institutional governance and that they were the least of all reference groups within the school involved in major educational decision-making and often completely excluded. The study discovery suggested that there were students' representation and participation in decision-making at strategic levels of the University and so could influence strategic decisions in their favour, particularly in the fixing/increases of fees, given that fees accounted for a substantial proportion of University's Internally Generated Funds.

However, it was found that students' representation and participation in decision-making at these management levels did not have much influence on management's decisions about student issues. The combined results of all respondents to this study showed largely that students' representation and participation in decision-making at these management levels was just to fulfill legal/formal requirements of the University Statutes and so had little influence over management decisions. Up to $82.5 \%$ of the respondents had this view. A management respondent remarked:

"Some of the conflicts could have been avoided if management listened to and took steps to address concerns of students. After all, students had represented and participated in some key levels of management including the University Governing Council and needed to be listened to. But it appears to me that their representation was always a mere formality with little influence, if at all on management decisions" (Interviews, January, 2017).

Only $5 \%$ however, were of the view that students significantly influenced management decisions through representation and participation. The respondents believed that management could have taken advantage of the students' representation and participation in the decision making processes to ensure that students demands were quickly brought to their notice and addressed to reduce the occurrence of conflicts.

Regarding the level of fee fixing/increases, it was revealed that students' in- 
volvement had only a moderate influence. Except 5\% student respondents who said they had significant influence over fee fixing/increases as they witnessed in $2005 / 2006$, the remaining $95 \%$ of student respondents and all (100\%) management respondents to the study believed students' involvement only moderately influenced the level of fee fixing/increase in the University. Asked as to why the students' representation and participation had little influence on management decisions, a management member in an interview responded:

"Management was cunning. It would fix the fees, meet students and push them to accept and make it look like they took the decision together; causing conflicts between it and the students" (Interviews, January, 2017).

Other causes of the conflicts between students and management of the University as in Table 2 and Table 3 included: the existences of drastic and obnoxious rules and regulations, the activities of campus secret cults, differences in the perception of group and organizational objectives, poor institutional leadership, increased awareness of students' rights and their power to influence management decisions, influence of complex students' social background and youthful exuberance, management role overload and widespread corruption allegations on campus. These causes were however, indicated by respondents as not significantly causing the conflicts compared to those discussed earlier in detail.

Drastic and obnoxious rules and regulations were mentioned as part of the causes of the conflicts. Some respondents cited the prevention of students from writing examination for owing Academic Facility User Fees (AFUF) and not allowing a student to write a trimester examination for not taking part in preceding third trimester field practical programmes as was the precursor to the 2001 conflict as examples of drastic and obnoxious rules and regulations.

Also, students of the Medical School saw management's imposition of the Problem Based Learning (PBL) on them as obnoxious. Even though students claimed they had concerns with the non-accreditation of the Medical Schools programmes among other concerns and so had to express their disappointments by attacking management, the issue of the PBL was said to be the main cause of the 1999 conflict between students and management in Tamale. In this conflict, a management official was physically assaulted by students leading to the rustication of some student leaders. This was in line with the observation of Alabi (2002: p. 3) that older members of the university— "academic and administrators often impose rules and regulations". In return, "the young may answer back by demanding for, and claiming, their democratic rights, culminating in minor conflicts or even ghastly skirmishes between the students and the university authority".

Whereas majority of all the study respondents (87.5\%) were uncertain, $12.5 \%$ of them believed that the activities of secret cults were on the increase on the University campuses and posing as threat to lives and campus security generally. This corroborated the arguments by UDS (2010) and Ekundayo \& Ajayi (2009) that the situation on occultism remained an issue of concern on university campuses. 
With the exception of $5 \%, 95 \%$ of all the respondents to the study agreed that poor/ineffective leadership was the cause of many of the conflicts between students and management of the University during the period. A management member believed the conflicts occurred because of leadership failures; including the dictatorial and repressive leadership behaviors of management. This confirmed Adepoju \& Sofowora's (2012) assertion that leadership ineffectiveness in the management of the university contributed to growing levels of conflicts between students and management.

The nature of students (nonchalant youthful exuberance) and varied complex social background as opposed to the matured nature of management was also identified by $50 \%$ student and $35.7 \%$ management respondents as high; contributing to incompatibilities and to student-management conflicts in the University. This was a view shared by researchers such as Onyenoru (1996), Adebayo (2009), Adepoju \& Sofowora, (2012) and Bua et al. (2015) in similar works. Also, part of the causes of the conflicts found was the activities of students' unionisms in the University; referred to as militant student unionism by Ekundayo \& Ajayi (2009). Respondents believed some of the conflicts resulted from the militant and demagogic behavior of student leaders. For example, a management respondent in an interview stated:

"The student leader was a 'demagogue, who during the 2008/2009 took advantage of ailing infrastructural and other conditions of the time to incite students to enhance his popularity. This was what such a leader was noted for in his previous institution of studies before coming to study in UDS" (Interviews, January, 2017).

Ekundayo \& Ajayi (2009) argued that militant student unions reacting aggressively to problems in the university often lead to student management conflicts as was the situation in the $2008 / 2009$ on Wa Campus of the University. On the issue of widespread corruption allegations on campus, respondents referred to three instances in 2001, 2004 and 2006 where alleged students and management complicity in corrupt practices led to students-management conflicts. A respondent remarked:

"One other reason for the students-management conflicts was the activities of certain university officials who were often accused of complicity in the nefarious and corrupt activities of some student leaders and who therefore would do everything possible to conceal the truth of such activities. Some management officials also showed they were irresponsible in the handling of resources needed to provide the required facilities for students to conveniently study" (Interviews, January, 2017).

Consequentially, Adebayo (2009) revealed that students-management conflicts could be caused by strong and widespread allegation of corruption in higher places in and out of campus.

Respondents to this study were also of the view that management's approach to student's behavioural issues in the University was another cause to the conflicts. It was established that management often failed to persuade and inspire 
students for behavioural changes in times of disagreement and would not even express the disagreements in a reasonable manner as would have been desirable in building consensus and avoiding conflict. Instead, management of the University mostly threatened and punished students for potential behavioural changes. A respondent expressed:

"Management expressed disagreement in arrogant and demeaning manner and also suppressed students interest with their power and authority. These in turn produced negative reactions from students".

Baron (1984) opined that disagreement expressed in an arrogant and demeaning manner produce significantly more negative effects than the same sort of disagreement expressed in a reasonable manner. Youngs (1986) adding to this argument said that threats and punishment by one party in a disagreement tended to produce intensifying threats and punishment from the other party. This is what happened in 2008/2009 in Wa. A respondent remarked:

"I believe that what seemed a disagreement would not travel far if management listened to our concerns. We did not mean harm but management just would not listen to us. We tried our best to let management realize that we were out for the good of students, management and the entire university but management had no patience and the humility to listen to us. I saw this as a leadership weakness. The leader of management was a bully, a dictator and lacked leadership. This is why we had to hit the ground rolling to press home our demands and I can tell you that he did not take it easy when The Chronicle newspaper published our concerns-a student leader said' (Interviews, January, 2017).

\section{The Disciplinary Situation in the University at the Time of Analysis}

The study showed that the general disciplinary situation between students and management alike in the University during the period examined was of a moderate account. This was the overall assessment by both categories of respondents to the study. On respondent category specific bases however, there were divergent views between student respondents and management respondents on this issue. Whereas $50.1 \%$ of student respondents pointed to the fact that the situation was bad, $52 \%$ of management respondents felt it was good. On a collective note however, student and management respondents rated the moderate situation of discipline at the time at $49 \%$ and $47.9 \%$ respectively. Only $15 \%$ student respondents believed the disciplinary situation of the time was good. None said it was very bad as none also said it was very good. On their part, none of the management respondents also believed the situation was bad or very bad nor very good. With Fayol's (1930) recognition of discipline as key to the functioning of organizations and organizational stability, it could be argued that the moderate nature of discipline in the University made it fragile and exposed it to the conflicts of the time.

\section{Conclusion}

This paper concluded that conflicts were high and worrying in the University for 
Development Studies from 1999 to 2009 and that these were largely conflicts between students and university management. Wide communication gaps between students and university management, infrastructural deficiencies and leadership crises were the major drivers of the conflicts.

\section{Limitation and Direction for Future Research}

Any flaws to the study primarily had to do with the collection of data, given the caliber of respondents to the study. There were difficulties getting some respondents in the right setting, especially, management members to administer questionnaires and interview. Data collected in such circumstances could be marred. Also, as Marshal and Rossman (1995) noted, some respondents who were directly affected by the conflicts were not only uncomfortable and tried to avoid responding to some questions, but also, tried sometimes to divert attention to some discussions that had no relevance to the study. Also, some respondents could not remember all that happened during the conflicts due to the lapse of time. Inferences therefore had to be made from responses that could not be taken wholesale. Notwithstanding the above limitations, relevant data was obtained for the study through the use of multiple sources and methods as well as crosschecks beyond respondents.

\section{Recommendations}

The paper recommended that efforts be made to enhance communication at all levels of the University especially between students and management, involve students in decision making, improve students-management dialogues and set and ensure effective functioning welfare and counseling committees/units, provide adequate infrastructure, provide effective institutional leadership and stamp out occultism.

Intensifying teaching of courses on peace, conflicts management and resolution in the University across all programmes is also recommended. Students should be taught to know the consequences of the conflicts, especially, the negatives and how they (the students) suffer the most during such conflicts and therefore the need to engage in peaceful resolution rather than to resort to violence.

\section{Conflicts of Interest}

The author declares no conflicts of interest regarding the publication of this paper.

\section{References}

Ada, A. J. (2013). Conflicts as Constraints to Effective Management of Tertiary Institutions in Nigeria: The Way Forward. Mediterranean Journal of Social Sciences, 4, 77-83. https://doi.org/10.5901/mjss.2013.v4n8p77

Adebayo, F. A. (2009). Student-Authority Conflict in Nigerian Universities. The Social Sciences, 4, 489-493. http://medwelljournals.com/abstract/?doi=sscience.2009.489.493 
Adegbite, J. G. O. (2007). The Education Reform Agenda: Challenges for Tertiary Education Administration in Nigeria. In The Sixth Annual Seminar of the Conference of Registrars of Colleges of Education in Nigeria (South West Zone).

Adepoju, T. L., \& Sofowora, A. O. (2012). Management of Conflict and Aggressive Behavior by Administrators of Institutions of Higher Learning: the Case of South Western Nigeria. Review of Higher Education in Africa, 4, 85-117.

Adeyemi, T. O., Ekundayo, H. T., \& Alonge, H. O. (2010). Managing Students' Crisis in Tertiary Institutions in Nigeria. Journal of Research in National Development, 8, 1-15.

Ajibade, D. (2013). Students' Crisis in Nigerian Tertiary Educational Institutions: A Review of the Causes and Management Style. Khazar Journal of Humanities and Social Sciences, 16, 56-76. https://doi.org/10.5782/2223-2621.2013.16.1.56

Akparep, J. Y., Jengre, E., \& Mogre, A. A. (2019).The Influence of Leadership Style on Organizational Performance at TumaKavi Development Association, Tamale, Northern Region of Ghana. Open Journal of Leadership, 8, 1-22. https://doi.org/10.4236/oj1.2019.81001

Alabi, A. T. (2002). Conflicts in Nigerian Universities: Causes and Management. Ilorin Journal of Education (IJE), 21, 102-114.

Babbie, E. (2005). The Basics of Social Research (3rd ed.). Belmont: Thomson/Wadsworth.

Baker, T. L. (1994). Doing Social Research (2nd ed.). New York: McGraw-Hill, Inc.

Boateng, C. (2008). The Pathetic Story of UDS: Poor Furniture, PA System in Lecture Halls...Massive Demo on Monday. The Chronicle News Paper.

Bua, F. T., Ada, J. N., \& Akinde, E. U. (2015). Conflict Management and Resolution for the Sustainability of Educational Institutions in Nigeria. Journal of Literature, Languages and Linguistics, 6, 58. http://www.iiste.org

Burgess, T. F. (2001). Guide to the Design of Questionnaires. Leeds: University of the Leeds.

https://nats-www.informatik.uni-hamburg.de/pub/User/InterculturalCommunication/ top2.pdf

Creswell, J. W. (2014). Research Design: Qualitative, Quantitative, and Mixed Methods Approaches (4th ed.). Thousand Oaks, CA: Sage Publications.

Denzin, N. K. (1989b). The Research Act (3rd ed.). Englewood Cliffs, NJ: Prentice Hall.

DuBrin, A. J. (2010). Principles of Leadership (6th ed.). Mason, OH: South-Western Cengage Learning.

Ekundayo, H. T., \& Ajayi, I. A. (2009). Towards Effective Management of University Education in Nigeria. International NGO Journal, 4, 342-347. http://www.academicjournals.org/INGOI

Flick, U. (2002). An Introduction to Quality Research (2nd ed.). London: Sage Publications.

Gray, D. E. (2004). Doing Research in the Real World. London: SAGE Publications.

Havenga, W., \& Visagie, J. (2011). Managing Conflict in a South African Non-Profit Organization: An Analysis of Conflict Generating Factors and Conflict Management Styles. Journal of International Management Studies, 6.

http://www.jimsjournal.org/22\%20Werner\%20Havenga.pdf

Ibukun, W. O. (1997). Educational Management: Theory and Practice. Ado-Ekiti: Green Line Publishers.

Ige, A. M. (2014). The Challenges of Being a Student of Any Public Tertiary Institution in Nigeria of Today. Journal of Studies in Education, 4, 128-141. 
https://doi.org/10.5296/jse.v4i1.1261

Kreitner, R. (2001). Management (8th ed.). Boston, MA, New York: Houghton Mifflin Company.

Lawson, C. (2009). Dangers of Reiki: Warning about a Dangerous Occult Practice. http://www.spiritual-research-network.com/dangers_of reiki.html

Marshall, C., \& Rossman, G. B. (1995). Designing Qualitative Research (2nd ed.). Thousand Oaks, CA: Sage.

Maslow, A. H. (1943). A Theory of Human Motivation. Psychological Review, 50, 370-396. https://doi.org/10.1037/h0054346

Mason, J. (2002). Qualitative Research (2nd ed.). Thousand Oaks, CA: Sage Publications Ltd.

Miles, M. S., \& Huberman, A. M. (1984). Qualitative Data Analysis. A Source Book of New Methods. Beverly Hills, CA: Sage.

Ogunbameru, O. A. (2004). Personality Dimension to Cultism in Nigerian Tertiary Institutions: A Sociological Perspective. Journal of Human Ecology, 16, 91-98. https://doi.org/10.1080/09709274.2004.11905721

Olaleye, F. O., \& Arogundade, B. B. (2013). Conflict Management Strategies of University Administrators in South-West Nigeria. Kuwait Chapter of Arabian Journal of Business and Management Review, 2, 96-104. https://doi.org/10.12816/0001212

Onyenoru, I. P. (1996). Nature and Management of Students' Conflict. Sociology Series No. 4, Ibadan: University of Ibadan, Department of Sociology.

Rothman, J. (1992). From Confrontation to Cooperation: Resolving Ethnic and Regional Conflict. Thousand Oaks, CA: SAGE Publishers, Inc.

Sarantakos, S. (2005). Social Research (3rd ed.). London: Palgrave Macmillan. https://doi.org/10.1007/978-0-230-20901-5

Smah, O. S. (2007). Violent Campus Cultism: Implication for University Management. In J. B. Babalola, \& B. O. Emunemu (Eds.), Issues in Higher Education: Research Evidence from Sub-Sahara Africa. Lagos: Bolabay Publications.

Stone, M. (1999). How to Resolve Conflict at Work: A Take Charge Assistant Book. New York: Amacom.

Twumasi, P. A. (2001). Social Research in Rural Communities (2nd ed.). Accra: University Press.

UDS (2009). Minutes of the 61st Meeting of the UDS Governing Council, Tamale, Ghana.

UDS (2010). Minutes of the 65th Meeting of the UDS Governing Council, Tamale, Ghana.

UDS (2011). Minutes of the 66th Meeting of the UDS Governing Council, Tamale, Ghana.

UDS (2016). Dairy. Tamale: University Relations.

Wall Jr., J. A., \& Callister, R. R. (1995). Conflict and Its Management. Journal of Management, 21, 515-558. https://doi.org/10.1177/014920639502100306 